\title{
International Relations: Spanish, Italian, French, English and German Printed Single Event Newsletters Prior to Renaudot's Gazette
}

\author{
Henry Ettinghausen
}

The work done on the early periodical press by the 'News Networks in Early Modern Europe' project is extremely important. ${ }^{1}$ After all, from its first appearance, early in the seventeenth century, the gazette-type periodical was quite rapidly to become the dominant model of printed news, and it has remained so ever since. However, news in print did not begin with the periodical press. From the end of the fifteenth century until the beginning of the seventeenth, the press had consisted entirely of non-periodical news pamphlets, often drafted in the form of letters and nearly always treating a single event. ${ }^{2}$

It is no doubt, at least in part, precisely because the non-periodical single event newsletters did not give birth to the modern press that, in general, relatively little attention has been paid to them. ${ }^{3}$ In Spain, however, where they remained the predominant news medium until way beyond the middle of the seventeenth century, the relaciones de sucesos (reports of events), as those non-periodical single event newsletters are known, have received a great deal of attention. Indeed, in the 1990s scholarly interest in them led to the creation

1 This chapter forms part of the Project HUM-2005-02482-FILO, located at the University of Girona. It was written as a preview of Henry Ettinghausen, How the Press Began. The PrePeriodical Printed News in Early Modern Europe, SIELAE, 2015, available free online at <http:// www.janusdigital.es/anexos.htm $>$ [23/3/16].

2 In the course of the sixteenth century, a very small minority of news pamphlets combined two or three news stories, and, before the end of the century, a few news pamphlets were published as series. Carmen Espejo refers, very pertinently, to the at times indeterminate distinction between what is periodical, and what is pre-periodical, noting that this involves sometimes including in histories of journalism, and at others excluding from them, English newsletters or Spanish relaciones de sucesos, or else consigning them to an initial chapter on 'precedents', even in the specialist literature (see Carmen Espejo, 'Un marco de interpretación para el periodismo europeo en la primera Edad Moderna', in La aparición del periodismo en Europa. Comunicación y propaganda en el Barroco, ed. Roger Chartier and Carmen Espejo [Madrid: Marcial Pons Historia, 2012], pp. 103-26, at 104).

3 As Carmen Espejo rightly says, the relaciones de sucesos lie at the origin, but are not themselves the origin, of modern journalism (see 'Un marco de interpretación', p. 107).

(C) HENRY ETTINGHAUSEN, 2016 | DOI 10.1163/9789004277199_012

This is an open access chapter distributed under the terms of the Creative Commons Attribution-

Noncommercial-NoDerivatives 3.o Unported (CC-BY-NC-ND 3.o) License. 
of the SIERS, the 'Sociedad Internacional para el Estudio de las Relaciones de Sucesos', the only scholarly association, it would seem, entirely dedicated to the study of the genre. However, neither in Spain nor elsewhere, as far as I know, has much thought been given to the fact that the single event nonperiodical newsletter had become an international phenomenon, based onand doubtless further developing-Europe-wide news networks, long before the birth of the periodical press.

What I propose doing here is to exploit several studies, nearly all of them published in the 1960s, which unknowingly showed that those early printed single event newsletters ought to be formally recognised as constituting a panEuropean phenomenon. For the sake of clarity, I shall call non-periodical single event pamphlets newsletters, and I shall refer to gazette-type multiple event serial periodicals as newspapers. And I shall take as my end point the launch of Théophraste Renaudot's Gazette in 1631, the moment when the newspaper first becomes established as an official, government supported, news medium.

\section{The Printed Newsletter in Europe}

\section{Spain}

In 1966 Mercedes Agulló y Cobo published a bibliography of nearly 800 relaciones de sucesos printed between 1477 and $1619 .{ }^{4}$ It was prefaced by an introductory note, just over one page long, in which she stated - with just a little exaggeration - that the relaciones de sucesos cover all the topics to be found in a modern newspaper, namely: international politics, war, social affairs (such as royal weddings, royal births and official celebrations), fires, miracles, bloody crimes and the weather (by which, no doubt, she meant hurricanes, floods, and so on). ${ }^{5}$ She could, however, have added that they also include other kinds of court news (such as royal journeys, royal deaths and triumphal entries) and

4 Mercedes Agulló y Cobo, Relaciones de sucesos I: Años 1477-1619 (Madrid: Consejo Superior de Investigaciones Científicas, 1966). Agulló takes her bibliography up to 1626 in 'Relaciones de sucesos (1620-1626)', in Homenaje a Don Agustín Millares Carló (Gran Canaria: Confederación Española de Cajas de Ahorros, 1975), vol. 1, pp. 349-8o. Earlier pioneering works on relaciones de sucesos include Jenaro Alenda y Mira, Relaciones de solemnidades y fiestas públicas de España (Madrid: Sucesores de Rivadeneyra, 1903); Relaciones de los reinados de Carlos Vy Felipe II, prologue by Amalio Huarte, 2 vols. (Madrid: Sociedad de Bibliófilos Españoles, 1941); José Simón Díaz, 'Algunas relaciones de sucesos de los años 1540-165o', Biblioteca Hispana, 15 (1957), pp. 506-23.

5 Agulló y Cobo, Relaciones de sucesos I, p. 3. 
Church news (such as conversions, beatifications, canonisations, martyrdoms and autos de fé), other types of natural disaster (such as earthquakes and volcanic eruptions), other kinds of sensational news (such as the birth of conjoined twins and other malformed humans, the appearance of monsters or dire doings of the devil), as well as sports (such as tournaments, quintain and bullfights).

In addition, she could have mentioned the following essential features of the relaciones de sucesos: first, they derived from a long tradition of letters and reports written by hand-especially by diplomats, missionaries, soldiers, spies and businessmen - a practice which continued long after news started going into print; secondly, many of them were written in verse and were designed to be recited in public; thirdly, the opinions they expressed represented what we would call 'the Establishment', or established authority and institutions; fourthly, they did not just pretend to provide information, but 'structured' reality, whilst amazing, sermonising or shocking their readers and listeners; and finally, in the second half of the sixteenth century and the first half of the seventeenth, they were doubtless the most widely read form of printed matter in Spain. Much of the important work done on the relaciones de sucesos in the past couple of decades may be found in the published proceedings of the six conferences held, to date, by the SIERS. ${ }^{6}$

\section{Italy}

As far as Italy and France are concerned, one could almost be tempted to suspect the presence of a conspiracy to cover up the existence of single subject printed newsletters there. In both countries, although isolated attempts were made in the 1960 s at least to list them, those attempts fizzled out like damp squibs. In Italy, a great deal of work has been done, most especially by Mario Infelise, on manuscript newsletters and newspapers produced in the fifteenth to seventeenth centuries, but next to nothing has been written about printed single subject Italian newsletters, which is not to say that they did not exist. In fact, in 1967, Tullio Bulgarelli published Gli avvisi a stampa in Roma nel cinquecento, the only important follow-up to which that I am aware of is its sequel, Il giornalismo a Roma nel seicento, by Sandro and Tullio Bulgarelli. ${ }^{7}$ Both bibliographies are based solely on the holdings of libraries in Rome.

6 The website $<$ www.bidiso.es/boresu/ $>$, located at the Universidade da Coruña, contains upto-date information about the sIERs, including its proceedings, as well as invaluable primary and secondary bibliography on relaciones de sucesos.

7 Tullio Bulgarelli, Gli avvisi a stampa in Roma nel cinquecento. Bibliografia, antología (Rome: Istituto di studi romani, 1967); Sandro and Tullio Bulgarelli, Il giornalismo a Roma nel seicento. Avvisi a stampa e periodici italiani conservati nelle biblioteche romane (Rome: Bulzoni editore, 1988). 
Avvisi a stampa does not sound very much like relaciones de sucesos, but the two are very similar indeed, for the avvisi, too, nearly always contain news concerning single events. For the sixteenth century, Tullio Bulgarelli lists 354 avvisi, printed in 24 Italian cities; and, for the seventeenth, he and Sandro Bulgarelli list over twice as many: 723 items printed in 55 cities. To judge by the data they provide, the production of arvisi a stampa reached a peak between 1620 and 1640, a feature that coincides closely with what we know about the relaciones de sucesos. ${ }^{8}$

As for the reasons why the avvisi a stampa have been virtually ignored, Tullio Bulgarelli noted the widespread assumption amongst Italian historians that manuscript avvisi, rather than printed ones, lay at the origins of the modern newspaper. ${ }^{9}$ It is an assumption that still persists. Mario Infelise, who regards the periodicity of the manuscript avvisi as the defining feature of the press, dismisses the newsletters printed in Italy since at least the beginning of the sixteenth century on the grounds that the latter did not establish contact with what he calls "the authentic public" which, according to him, only fixed periodicity was capable of promoting. ${ }^{10}$

As regards the content of the printed avvisi, which, as Tullio Bulgarelli notes, generally (like the relaciones de sucesos) took the form of letters, he makes it clear that in the sixteenth century they provided news from the entire known world and covered the same types of news as the relaciones, notably battles, conspiracies, festivities, royal weddings, treaties, trials, geographical discovery,

For an attempt to trace the development in the production of the relacones de sucesos in the sixteenth and seventeenth centuries, see Henry Ettinghausen 'La prensa preperiódica española y el Barroco', in Géneros editoriales y relaciones de sucesos en la Edad Moderna, ed. Maria Eugenia Díaz Tena (Salamanca: SIE RS, 2013), pp. 89-102.

9 See Bulgarelli, Gli avvisi a stampa, pp. 13-14.

10 "Al principio, durante el siglo XVI, se sabe que ocasionalmente se habían estampado hojas volantes que tuvieron una gran difusión popular porque narraban batallas, ceremonias públicas y otros hechos capaces de estimular el interés común, pero que no establecían aquel contacto con el auténtico público que únicamente una periodicidad fija era capaz de alimentar" (Mario Infelise, 'Los orígenes de las gacetas. Sistemas y prácticas de la información entre los siglos XVI y XVI', Manuscrits, Revista d'Història Moderna, Universitat Autònoma de Barcelona, 23 [2005], pp. 31-44, at 40). For her part, Carmen Espejo holds that "the somewhat mechanical and simplistic explanation that journalism was born with and through printing cannot be maintained" ("European Communication Networks in the Early Modern Age: A New Framework of Interpretation for the Birth of Journalism', Media History, 17 [2011], pp. 189-202, at 192). Indeed, journalism-depending on how one defines it - may be thought to have begun long before the printing revolution, or else a century or more afterwards, but it still seems to be reasonable, and true, to say that the press begins with the establishment of printing. 
natural events and miracles. ${ }^{11}$ In addition to these, however, the items he catalogues also include coronations, royal journeys or progresses and triumphal entries; the deaths of kings, princes, popes and cardinals; the reception of ambassadors; and tournaments, martyrdoms and murders. War looms very large in the avvisi a stampa, as in the relaciones de sucesos, in particular the Turkish threat to Christendom, the struggle between Spain and France for supremacy in Europe, and the wars between Catholics and Protestants, the many reports of battles almost invariably being accounts of victories.

As for the seventeenth century, Sandro Bulgarelli shows that the avvisi a stampa continued to cover much the same range of topics as the relaciones de sucesos: events to do with European politics; battles against the Turks and the Barbary pirates; the birth and death of sovereigns and popes; ceremonies and celebrations; natural disasters, portents and miracles. ${ }^{12}$ His bibliography also contains, amongst avvisi published before 1631, news of coronations; journeys by monarchs, princes and popes; the persecution of Protestants; conversions, beatifications, canonisations and martyrdoms; fires, murders, monsters, and spectacular supernatural events. ${ }^{13}$

\section{France}

In France and in England a lot of work has been done on pamphlets, propaganda, popular prints, gazettes and corantos, but a great deal less on early single subject printed newsletters. Eugène Hatin's eight-volume Histoire politique et littéraire de la presse en France does not mention a single news publication prior to Renaudot. ${ }^{14}$ However, in the case of France, too, we find once again that pioneering works were published in the 196os: notably, two books by JeanPierre Seguin. His L'information en France, de Louis XII à Henri II describes and catalogues a total of 365 occasionnels (the French equivalent for relaciones de sucesos and avvisi a stampa) published up to $1559 \cdot{ }^{15} \mathrm{He}$ notes that roughly a third deal with the doings of the monarchy and the aristocracy, particularly

11 See Bulgarelli, Gli avvisi a stampa, pp. 18-19, 21. To be sure, very few relaciones de sucesos deal with conspiracies or lawsuits, and most of the Spanish accounts of voyages of discovery-like most of those published elsewhere-are book-length, rather than newsletters.

12 See Bulgarelli and Bulgarelli, Il giornalismo, p. xviii.

13 Like Mercedes Agulló y Cobo with relaciones de sucesos, the Bulgarellis deliberately leave out of account avvisi a stampa written in verse.

14 See Eugène Hatin, Histoire politique et littéraire de la presse en France: avec une introduction historique sur les origines du journal et la bibliographie générale des journaux, 8 vols. (Paris: Poulet-Malassis et de Broise, 1859-61).

15 Jean-Pierre Seguin, L'information en France, de Louis XII à Henri II (Geneva: E. Droz, 1961). 
royal births, journeys, festivities, marriages and deaths. ${ }^{16}$ However, like their equivalents in Spain and in Italy, the majority of them cover military affairs, with some victories giving rise to numerous reports, often published in several different towns. Seguin lists eight occasionnels on the French conquest of Genoa in 1507 , ten on battles with the Venetians in 1509, eleven on military operations in Italy in 1544, eleven more on the capture of Thionville in 1558 , and ten on the taking of Calais from the English that same year. ${ }^{17} \mathrm{He}$ also points to the frequent reprinting of occasionnels by different printers, a feature of newsletters also to be found elsewhere. ${ }^{18}$

Seguin's other outstanding book, his study and bibliography of over 500 canards, covers the century from 1529 to $1631 .{ }^{19}$ The canards - printed newsletters reporting sensational or sensationalist news - correspond to one variety of Spanish relaciones de sucesos and Italian avvisi a stampa that includes accounts of such items as murder, adultery, incest, rape, the birth of conjoined twins, natural disasters, monsters, comets, wizards, ghosts, and evils inflicted by the devil. Like newsletters printed elsewhere in Europe, the canards insist almost unanimously on the idea that disasters and portents are providential warnings and/or divine punishments for human sins and signify the need for mass penitence. ${ }^{20}$

\section{England}

In England the breakthrough in the study of newsletters was, likewise, made known in the 196os, when Matthias A. Shaaber's PhD thesis Some Forerunners of the Newspaper in England (published by the University of Pennsylvania Press in 1929) was reissued in London. ${ }^{21}$ Although it is a study, rather than a bibliography, Shaaber's book provides ample documentation. Like the Bulgarellis and Seguin, Shaaber is quite clear that "news (plus the printing press) created the newspaper", and he highlights the originality of his enterprise when he states that earlier histories of the English press had ignored the 150 years preceding

16 See Seguin, Linformation en France p. 29.

17 See Seguin, L'information en France, p. 30.

18 See Seguin, L'information en France, p. 25.

19 Jean-Pierre Seguin, L'information en France avant le périodique: 517 canards imprimés entre 1529 et 1631 (Paris: G.-P. Maisonneuve et Larose, 1964). Far more recently, the texts of 63 canards have been published in Maurice Lever, Canards sanglants. Naissance du fait divers (Paris: Fayard, 1993).

20 See Seguin, Linformation en France avant le périodique, pp. 53-64.

21 Matthias A. Shaaber, Some Forerunners of the Newspaper in England, 1476-1622 (1929; London: Frank Cass, 1966). 
the first periodical press. ${ }^{22}$ In his words, the earlier news is "a record of affairs of state, of war and battle at sea and on land, of the conduct of the great magnates, the heroes, and the personalities of the age, of murders, deeds of violence, and acts of God". ${ }^{23}$ More specifically, he documents royal births, visits, festivities, marriages and deaths; foreign embassies; and the trials and executions of noblemen and women accused of treason or rebellion, and of heretics and common criminals. He also notes that news of war predominates and "is one of the first kinds to appear at the beginning of the sixteenth century". ${ }^{24}$ In England - more so, no doubt, than in Spain, Italy or even France - a great deal of the news in the sixteenth century was inextricably intertwined with political and religious propaganda. ${ }^{25}$

Shaaber stresses the unspoken requirement that in England - as, in general, elsewhere- "as far as matters touching the credit of the state were concerned, the only kind of news fit to print was good news". ${ }^{26}$ Observing that news had to be "extraordinary, sensational, prodigious", he gives a detailed account of what he calls popular news: "murders and other crimes; miracles, prodigies, and wonders; monstrous births and strange beasts; witchcraft; the plague; acts of God, such as flood and fire, and the weather; and sporting events". ${ }^{27}$ The coincidence of these topics with those of the French canards, and their equivalents in Spain and Italy, is striking indeed. ${ }^{28}$

Some newsletters seem to be out to win the prize for the most outlandish story. To take just three examples, whilst a relación printed in Cadiz in 1622 relates the case of a man in the East Indies who was 380 years old, had been married eight times and had grown a third set of teeth, and one published in Seville in 1633 tells of a well-born Irish woman who delivered 370 children at one sitting into a silver dish, an English broadside published in about 1620 tells how a rich woman who mocked her poorer sister for bearing twins was punished by giving birth, at one go, to 365 children. ${ }^{29}$ Again, as elsewhere, the wonders and

22 See Shaaber, Some Forerunners, p. 3.

23 Shaaber, Some Forerunners, p. 8.

24 Shaaber, Some Forerunners, p. 121.

25 See Shaaber, Some Forerunners, pp. 65-105.

26 Shaaber, Some Forerunners, p. 123.

27 Shaaber, Some Forerunners, pp. 9, 138.

28 Douglas C. Collins, A Handlist of News Pamphlets, 1590-1610 (London: South-West Essex Technical College, 1943) lists over thirty extant printed newsletters on murders just for the two decades $1590-1610$.

29 The first example is described in the вDRs ('Catálogo y Biblioteca Digital de Relaciones de Sucesos [siglos XVI-XVIII]'), accessible via <http://www.bidiso.es/Relaciones/> [9/9/15], no. 4912. The title of the second example (вDRs no. 5347), a newsletter written in verse by 
horrors highlighted in the English popular news were almost invariably portrayed as signs of "God's mercy or wrath, as warnings of the Day of Judgement, or as summons to repentance".30

\section{Germany}

Research on German newsletters began long before the 196os. Published fifty years earlier, Paul Roth's short study of Flugschriften includes a score of extant items printed before $1500 .{ }^{31}$ Stressing the genre's epistolary format, Roth names the main topics covered by it as battles, embassies, treaties, coronations, triumphal entries and significant funerals, as well as accidents, storms, portents, murders, executions, freaks, ghosts and witches. ${ }^{32}$ In an essay on 'The Origins of the German Press', Thomas Schröder notes the existence, in the course of the sixteenth century, of two basic types of printed news, which clearly also existed elsewhere: Flugschriften (i.e. news pamphlets, often entitled Neue Zeitungen) and Flugblätter (i.e. single sheet broadsides). ${ }^{33}$ Whilst the latter frequently covered the more sensational news and were often written in verse, amongst the topics covered by the former were, Schröder says, "religion and confessional disputes, and politics, as well as news about miracles, catastrophes, and crimes" ${ }^{34} \mathrm{He}$ also makes the important point, which clearly applies no less to newsletters printed elsewhere, that, in the sense that they tested out various forms of news coverage and presentation, they "can be described as the root of the modern press". ${ }^{35}$

one Fernando Álvarez, begins: Relacion muy verdadera en que se da cuenta de vna muger natural de Seuilla, que en tiempo de doze años que es casada ha parido cincuentay dos hijos y oy en dia esta viua. Cuentase de vna señora muy principal de irlanda que pario trezientos $y$ sesenta hijos en vna fuente de plata y los bautizaron. For the last example, see Shaaber, Some Forerunners, p. 150.

3o Shaaber, Some Forerunners, p. 148.

31 Paul Roth, Die neuen Zeitungen in Deutschland im 15. und 16. Jahrhundert (Leipzig: B.G. Teubner, 1914), p. 11.

32 See Roth, Die neuen Zeitungen in Deutschland, pp. 13- 17.

33 Schröder, 'The Origins of the German Press', in The Politics of Information in Early Modern Europe, ed. Brendan Dooley and Sabrina A. Baron (London: Routledge, 2001), pp. 123-50, at 128-9. Numerous early Neue Zeitungen are described and transcribed in Emil Weller, Die ersten deutschen Zeitungen herausgegeben mit einer Bibliographie (1505-1599) (Tübingen: H. Läupp, 1872).

34 Schröder, 'Origins of the German Press', p. 129.

35 Schröder, 'Origins of the German Press', p. 130. 


\section{Physical Characteristics}

Mercedes Agulló y Cobo implicitly defines relaciones de sucesos, not just by their being printed newsletters, but also by their length, limiting them to pamphlets of up to roughly 40 pages. ${ }^{36}$ In fact, the majority of them were either four or eight pages long. Relaciones de sucesos, like newsletters elsewhere, had circulated in manuscript prior to the introduction of the press, and many continued to do so, alongside (and often scarcely distinguishable from) private correspondence.

As regards their physical qualities, the first pages of newsletters normally stated not just the title of the piece, but also the place of printing, the name of the printer and the date of publication. They used different sizes of type to highlight the key terms in their titles, and they often exploited recycled generic illustrative woodcuts, though in Germany, especially in the Flugblätter, the illustrations were generally made to order and were of very high quality. ${ }^{37}$ However, their format in Italy and France was generally smaller than the quarto commonly used in Germany or the quarto or folio used in Spain, the avvisi usually being printed in octavo, 16 mo or $32 \mathrm{mo}$ pamphlets (and only occasionally in quarto), two or four folios in length, whilst the occasionnels were mostly small quartos or octavos, either four or eight folios long. As for England, newsletters generally ran to four to twelve folios, or else-in the form of proclamations or ballads - appeared as single sheet broadsides. ${ }^{38}$ Especially from the end of the sixteenth century, some printers and publishers throughout Europe devoted substantial resources to news publication. To cite just one example, in the course of the second half of the century, one provincial French printer, Benoist Rigaud in Lyon, produced over a thousand editions. ${ }^{39}$

In nearly all of the countries we have been looking at, we find that the beginnings of the news publishing industry go back to the end of the fifteenth century, with a gradual increase in the first half of the sixteenth, a greater impetus in the second half and then, for the most part, a much greater output from the final decade of the century. From what we have seen, it would appear to be rash to claim that the development of the printed newsletter was "very much a phenomenon of northern Europe", although it would seem to be true that a

$36 \quad$ See Agulló y Cobo, Relaciones de sucesos I, p. 3.

37 See Hermann Wäscher, Das deutsche illustrierte Flugblatt (Dresden: De Gruyter, 1955). In general, the only newsletters that commonly carried specially made illustrations were those that described monsters.

38 See Shaaber, Some Forerunners, p. 294.

39 See Andrew Pettegree, The Book in the Renaissance (London: Yale University Press 2010), p. 149 . 
larger number of sixteenth-century newsletters printed in Germany survive, compared with those printed elsewhere. ${ }^{40}$

\section{The Name of the Genre}

One reason why it has taken so long fully to realise that the early printed single subject newsletters were a pan-European phenomenon is, no doubt, the disparity of their nomenclatures-being known, as they are, in Spanish as relaciones de sucesos; in Italian, as avvisi a stampa; in French, as occasionnels or canards; in English, as newsletters or broadsides; in German, as Flugschriften, Neue Zeitungen or Flugblätter; and so on. However, they were not born with those names.

The titles of most of the earliest examples of single event newsletters avoid generic terms altogether, and just use headlines instead. Thus, in Spain, we find titles that begin: Eclipse del sol ... (1485), La dolorosa muerte del Principe Don Juan ... (1497), etc. ${ }^{41}$ And the same practice applied in Italy, France and England. ${ }^{42}$ From very early on, though, some newsletter titles begin with generic names. In Spain, the following are amongst the earliest: Tractado ... from around 1477; Coplas ... (couplets) from 1496; Romance ... (ballad) from around 1525; Discurso ... from 1529; Descripción ... from 1533; and so on. ${ }^{43}$ A similar variety occurs elsewhere.

\section{Nouvelles/News, etc.}

At the end of the fifteenth century, a common generic term used in France in the titles of occasionnels is Nouvelles ..., with Discours ... becoming frequent after the middle of the sixteenth century.4 ${ }^{44}$ Agulló y Cobo dates the earliest Spanish relación de sucesos entitled Nuevas ... (news) to around 1536, but she tentatively dates as printed eleven years earlier a pamphlet entitled Relacion de

\footnotetext{
40 Pettegree, Book in the Renaissance, p. 9.

41 See Agulló y Cobo, Relaciones de sucesos I, nos. 2, 6.

42 E.g. in Italy, La triomphale Entrata di Carlo (1535), ustC 854190; Li horrendi, \& spaventosi prodigij, \& fuochi (1536), ustc 802758, (see Bulgarelli, Gli avvisi a stampa, nos. 27, 34); in France: Le sacre du Roy trescrestien Loys douziesme (1498), USTC 53865; La prise du Royaume de Naples (1501), USTC 53870; or Lassault bataille et conquest sur les Genevoys (1507), ustC 30897, (see Seguin, L'information en France, de Louis XII à Henri II nos. 3, 13, 21); in England: The Confession and ende of Thomas Norton (1570), UsTC 516709; or The Scottish queens Burial at Peterborough (1587), USTC 511107. See Shaaber, Some Forerunners, pp. 116, 120.

43 See Agulló y Cobo, Relaciones de sucesos I, nos. 1, 3, 14, 27, 33, 41.

44 See Seguin, L'information en France, p. 21.
} 
las nuevas de Italia. ${ }^{45}$ English pamphlets with titles that begin with the word Newes date back at least as far as the 1540 s. $^{46}$

\section{Letter/Copy of a Letter, etc.}

The epistolary origin of the newsletters is also reflected in many titles. In sixteenth-century Italy, $17.5 \%$ of the 354 avvisi a stampa listed by Tullio Bulgarelli start with Lettera ..., Copia di una lettera ..., or similar. Seguin states that one of the most frequent terms in the titles of occasionnels is Lettre - the most commonly used variations being Copie d'une lettre ..., La coppie des lettres ... etc.with the earliest instances dating from the beginning of the sixteenth century. ${ }^{47}$ In Spain we find printed newsletters entitled Traslado de la carta ... at just the same time, and one of the first of very many entitled Copia de una carta ... occurs in the mid-1530s. ${ }^{48}$ According to David Randall, it is only at the end of the sixteenth century that English newsletters "began to acquire titles such as 'The Copy of a Letter', 'This Is a True Copy', etc.", though Shaaber quotes a title beginning An Epistle ... that dates from $1538 .{ }^{49}$ And in Germany some titles begin Brief ..., Sendbrief ..., Missive ..., Copie ... or Abschrift ... ${ }^{50}$

\section{Avviso}

Over $21 \%$ of the avvisi a stampa listed by Tullio Bulgarelli for the sixteenth century have titles that begin Avviso ... or Avvisi ..., Novi avvisi ... or Ultimi avvisi.... However, like the Italian term gazzetta, avviso became one of the names used on occasion elsewhere to designate a type of news report, in particular in Spain and in France. In Spain the term aviso is rare before the very end of the sixteenth century, when at least some of the examples occur in newsletters translated from Italian. In France in the 1580 os we find at least two Advis that may well be translations from Italian: Nouveaux advis de l'estat du Christianisme des pays et royaulmes des Indes Orientales et Jappon (Paris, 1582), and Advis de Rome tiré des lettres de l'évesque du Mans (Paris, 1589). Aviso seems, however, to have been uncommon in Germany or England.

45 See Agulló y Cobo, Relaciones de sucesos I, nos. 59, 31.

46 E.g. Hevy newes of an horryble earth quake whiche was in the cytie of Scharbaria in this present yeare of. Xlii (London, 1542), USTC 503284; Newes from Rome concerning the blasphemous sacrifice of the papisticall Masse (Canterbury, 1550), USTC 504453.

47 See Seguin, L'information en France, p. 21.

48 See Agulló y Cobo, Relaciones de sucesos I, nos. 16, 19 and 45.

49 See David Randall, Credibility in Elizabethan and Early Stuart Military News (Political and Popular Culture in the Early Modern Period) (London: Pickering \& Chatto, 2008), p. 21; Shaaber, Some Forerunners, p. 42.

See Roth, Die neuen Zeitungen in Deutschland, p. 13. 


\section{Relation}

Relación de sucesos is the modern Spanish term for a single event newsletter. It is based on the term relación (report, account), whose earliest appearance in Agulló's bibliography occurs in a newsletter printed in about 1517, entitled: Esta es una relacion de dos casos nuevamente acaescidos ... ${ }^{51}$ In 1525 we see the word standing on its own at the beginning of the title of Alfonso de Valdés's Relacion de las nuevas de Italia ..., a practice that was to become very common indeed. ${ }^{52}$ Then we find elaborations on the term that stress the truth (rather than the recentness), of the news, such as: Verdadera relación ... (1534), Relación muy verdadera ... (1538?), Relación cierta y verdadera ... (1542?), etc. From the middle, and especially from the last third, of the sixteenth century, the most common terms used in Spanish titles are Relación ... (with or without adjectives) and Carta ... or Copia de una carta ..., with Relación ... predominating from roughly the 1590s. Relación's spectacular success may be gauged from a collection of single subject newsletters published in Barcelona in the second and third decades of the seventeenth century, in which only $9 \%$ of the items are entitled Carta ..., Copia de una carta ... or Traslado de una carta ..., whereas the titles of an overwhelming $75 \%$ of them contain the term Relación. ${ }^{53}$ And-something which does not appear to have been fully realised up to now- the term was not confined to Spain.

Out of Tullio Bulgarelli's 354 sixteenth-century avvisi a stampa, 32 begin with Relatione ..., five with Vera relatione ..., two with Relatione vera ..., one with Piena relatione ... and one with Breve relatione ... - in all, over $11 \%$ of the total. In the seventeenth century, however, the picture in Italy, too, changes dramatically. ${ }^{54}$ Out of the 716 seventeenth-century items catalogued by Sandro and Tullio Bulgarelli, only a dozen have avviso or avvisi in their titles, thirty or so begin with Lettera ... or Copia d'una lettera ..., and another thirty use Ragguaglio.... But what predominates absolutely is titles beginning Relatione ..., in all, around 392 , which represents $55 \%$ of the total. ${ }^{55}$

Only one of the 365 pre-1560 occasionnels catalogued by Seguin contains Relation in its title: Relation de la journee excellente tenue par la majeste de lempereur (1530?), and I know of only two other occasionnels prior to the end of the sixteenth century that do so: Briefve relation de la guerre d'Irlande

\footnotetext{
$51 \quad$ See Agulló y Cobo, Relaciones de sucesos I, no. 22.

52 See Agulló y Cobo, Relaciones de sucesos I, no. 31.

53 See Notícies del segle XVII: La Premsa a Barcelona entre 1612 i 1628, ed. Henry Ettinghausen (Barcelona: Arxiu Municipal de Barcelona, 200o).

54 See Bulgarelli, Gli avvisi a stampa.

55 See Bulgarelli and Bulgarelli, Il giornalismo.
} 
(Brussels, 1596) and Translat de la relation faicte en langue espaignole ... de la forme de la derniere maladie \& mort de Sa dicte Maté (Antwerp, 1599). ${ }^{56}$ Thereafter, though, in France, too, the designation Relation ... becomes very common indeed.

As Shaaber states in respect of England, whilst newsletter titles often used such terms as Discourse ..., Report ..., Declaration ..., Description ... or Narration ..., "the word relation occurs most frequently in titles and even more often in the accounts themselves". ${ }^{57}$ Indeed, Shaaber cites eleven titles beginning A relation ..., fourteen beginning $A$ true relation ..., two beginning $A$ most true relation ..., and one beginning $A$ true and perfect relation ...58 The earliest of them was printed in 1592, but the term appears to become quite common from the very beginning of the seventeenth century.

As for Germany, Shaaber argues that, "from the fact that early seventeenthcentury German books of news were sometimes headed "Aviso [or Avisa], Relation oder Zeitung", it would appear that the term had some international currency". ${ }^{59}$ In fact, however, we know of German newsletters entitled Relation ... printed as early as the 1560 , and the practice becomes very common from the beginning of the seventeenth century. ${ }^{60}$

From the end of the sixteenth century, then, national variations of the term Relation (relación, relazione, relació, etc.) had taken off as the commonthough not exclusive-generic name used in the titles of printed newsletters in all those countries we have been looking at-and doubtless, too, in others. ${ }^{61}$

56 See Seguin, L'information en France, p. 89 .

57 Shaaber, Some Forerunners, p. 12.

58 See Shaaber, Some Forerunners, pp. 359-6o, 365, 354.

59 Shaaber, Some Forerunners, p. 12. The Aviso Relation oder Zeitung began printing in Wolfenbüttel from 1609 .

6o $\quad$ E.g. Relation und Extract von aussagen und besonderen Kundtschafften des Türckens ... (?1566); Warhaftige Relation vn[d] Bericht, Was massen die gewaltig Statt vnnd Beuestigung Famagusta, in Cipro (?1572), UstC 690554. Nearly a century and a half ago, Richard Grasshoff was already using the term Relationen as synonymous with Flugschriften: see Richard Grasshoff, Newen Zeytungen (Die briefliche Zeitung des XVI. Jahrhunderts) (Leipzig: C.W. Vollrath, 1877), p. 4.

61 It should, however, be noted that the term Relation did not refer exclusively to newsletters. It could, amongst other things, denote a list, or book-length accounts of voyages, missionary reports or autobiographies. The single event newsletter is not even mentioned in a recent volume of essays devoted to works entitled Relation (see Things Not Easily Believed: Introducing the Early Modern Relation, ed. Thomas V. Cohen, and Germaine Warkentin, special Issue of Renaissance and Reformation, 34.1-2 [2011]). 


\section{International Relations}

Printed non-periodical single event newsletters became, then, an ever more important fact of life in Western Europe from the end of the fifteenth century until well into the seventeenth. Their remarkably wide diffusion is attested, practically from the beginning, by their being reprinted in numerous different locations within several countries, most notably in Germany, Italy and France. Even more remarkably, though, they very soon began to cross national frontiers, transmitted along trade and postal routes that had been developed since well before the fifteenth century and which, from early in the seventeenth century, would start carrying the news that made up the new periodical newspapers. ${ }^{62}$ Ample evidence for the early recognition and organisation of European postal routes is contained in such works of the period as Giovanni da l'Herba's Itinerario delle poste per diuerse parti del mondo opera piaceuole, et vtile (Rome, 1563).

As we have seen, many (if not a majority of) printed newsletters brought news from abroad and actually advertised themselves in their titles as translations from foreign originals. To give just one instance, amongst a collection of 126 relaciones de sucesos published in Barcelona between 1612 and 1628, an overwhelming $76 \%$ give news of events that supposedly occurred either abroad or at sea, and as many as $10 \%$ of them actually state that they are translations. ${ }^{63}$ In England, too, news from abroad was far more abundant than home news, with at least three-quarters of foreign news coming from and concerning France and the Netherlands. ${ }^{64}$ Shaaber cites the case of John Wolfe who entered in the Register of the Stationers' Company, or actually published, some 150 newsletters before the end of the sixteenth century, two-thirds of them being translations of foreign originals; and he lists nearly forty English items published or entered in the Stationers' Register in 1590 on Henri IV's successes against the League. ${ }^{65}$ News from abroad - not least, wars, natural disasters, miracles, monsters and murders-was, clearly, lapped up by the English

62 For the development of the postal routes, see E. John B. Allen, Post and Courier Service in the Diplomacy of Early Modern Europe (The Hague: Martinus Nijhoff, 1972); Paul Arblaster, 'Posts, Newsletters, Newspapers: England in a European system of communications', in News Networks in Seventeenth-Century Britain and Europe, ed. Joad Raymond (London: Routledge, 2006), pp. 19-34 and Ch. 2, above.

63 See Notícies del segle XVII.

64 See Shaaber, Some Forerunners, pp. 168-9.

65 See Shaaber, Some Forerunners, pp. 286-7, 169-72. 
public. ${ }^{66}$ In France and Germany, as well, many of the occasionnels and Flugschriften are translations. To give just one early instance, a Flugschrift on an earthquake near the Canaries that was felt in Andalusia, Morocco and the Azores was published in Cologne in 1523, translated from Portuguese-a French edition, also translated from Portuguese, having appeared in Antwerp the previous year. ${ }^{67}$ In fact, so successfully networked were centres of production of printed single event newsletters that they were perfectly capable of creating what amounted to Europe-wide news stories.

The most emblematic early instance of the internationally transmitted press is doubtless the news of the 'discovery' of the New World. In 1493, Pere Posa printed in Barcelona, in a two-folio newsletter in folio, the account written by Columbus of his first transatlantic voyage. Columbus' letter was rapidly translated and was printed in over twenty editions in Seville, Rome, Florence, Pavia, Paris, Antwerp, Basel, Leipzig and Nuremberg - i.e in half a dozen different countries-by the end of the fifteenth century. ${ }^{68}$ Then, between 1503 and 1506, the letter attributed to Amerigo Vespucci, containing a description of the reconnaissance of the Brazilian coast by the Portuguese, came out in over thirty editions in France, Italy, the Netherlands and the German-speaking countries, where it was printed in Augsburg, Basel, Leipzig, Magdeburg, Munich, Nuremberg, Rostock and Strasbourg. ${ }^{69}$

The wars in Italy in the 1520 s between the Emperor Charles V and Francis I of France were covered in French, Italian, Spanish and German newsletters. ${ }^{70}$ Charles's victory over the French at Pavia in 1525 was celebrated in Dutch, German, Spanish and Italian, the Antwerp publisher Willem Vorsterman producing his news pamphlet within three weeks of the event. ${ }^{71}$ Charles's conquest

66 See Sara Barker, 'Strange News: Translations of European Sensational News Pamphlets and their Place in Early Modern English Culture', in The Book Trade in Early Modern England: Practices, Perceptions, Connections ed. John Hinks and Victoria Gardner (New Castle, DE: Oak Knoll Press and The British Library, 2013), pp. 161-86.

67 See Eulogio Varela Hervias and Gottfried Von Waldheim, Una relación alemana sobre el terremoto de Andalucía, Marruecos y Azores del año 1522 (Madrid: Comisión de Cultura e Información, 1948).

68 See Renate Pieper, Die Vermittlung einer neuen Welt. Amerika im Kommunikationsnetz des habsburgischen Imperiums (1493-1598) (Mainz: Philipp van Zabern, 2000).

69 See Pettegree, Book in the Renaissance, p. 132.

70 See Katrin Hirt, Die italienischen Kriege zwischen Karl V. und Franz I. in den Jahren 1521-1530: Medienereignisse in zeitgenössischen deutschen, italienischen und französischen Flugschriften, Dissertation zur Erlangung des wissenschaftlichen Grades eines Doktors der Philosophie im Fachbereich Geschichts- und Kulturwissenschaften der Justus-LiebigUniversität Gießen, 2010.

See Pettegree, Book in the Renaissance, p. 139. 
of Tunis ten years later inspired numerous newsletters in Spain, Italy and France. News of England in the mid-sixteenth century—not least Henry viII's break with Rome, and Philip II of Spain's marriage to Mary I-was amply recorded in the press in Italy and Spain. ${ }^{72}$ The execution of the Duke of Northumberland in 1553 made the news in English, German, Dutch and Italian. The defeat of the Turkish siege of Malta in 1565 was related in newsletters in Spanish, Italian, French, German and Dutch. In 1571 and 1572, over three hundred pamphlets reporting and celebrating the news of the Turkish defeat at Lepanto were published across Europe. ${ }^{73}$ Spaniards and Italians read accounts printed in their languages of the Saint Bartholomew's Day massacre in 1572; and Spaniards, Italians and Englishmen were shocked to read of the assassination of Henri IV in $1610 .{ }^{74}$ The Japanese diplomatic legation to Rome, begun in 1585 , made the news in Italy, France, Germany and Spain. News of the beheading of Mary Stuart in 1587 spread, with horror, throughout Catholic Europe. ${ }^{75}$ Plenty of newsletters were published in Italy, Germany and Spain in the 1590s on the war in Transylvania against the Turks. ${ }^{76}$ The taking of Calais by the Spanish in 1596 was publicised in newsletters printed in Spanish, Italian, French, Dutch and English. The Gowrie conspiracy, involving a supposed attempt to assassinate James VI of Scotland in 1600, was the news in a pamphlet printed at Edinburgh and is reported in an avviso published the same year in Venice and in two occasionnels. ${ }^{77}$

72 See José Solís de los Santos, 'Relaciones de Sucesos de Inglaterra en el Reinado de Carlos v', in Testigo del Tiempo, Memoria del Universo. Cultura Escrita y Sociedad en el Mundo Ibérico (Siglos $X V-X V I I I$ ), ed. Manuel F. Fernández, Carlos Alberto González, y Natalia Mallaird (Barcelona: Rubeo, 2009), pp. 640-98.

73 See Pettegree, Book in the Renaissance, p. 145.

74 For St. Bartholomew's Day, see M. Agulló y Cobo, Relaciones de sucesos I, no. 171; Bulgarelli, Gli avvisi a stampa, nos. 133, 135, 140, 141; for Henri IV, see M. Agulló y Cobo, Relaciones de sucesos I: nos. 480, 491; Bulgarelli and Bulgarelli, Il giornalismo a Roma, nos. 46-50, 55; Collins, Handlist of News Pamphlets, nos. CCLIX-CCLXI, CCLXVI, CCLXVII.

75 Alexander S. Wilkinson studies the impact in France of Mary's execution, using over 400 contemporary reports, sermons, etc. See Mary Queen of Scots and French Public Opinion, 1542-160o (Basingstoke: Palgrave Macmillan, 2004).

76 See Ch. 22, below; Rubén González Cuerva, “El prodigioso príncipe transilvano”: la larga guerra contra los turcos (1596-16o6) a través de las relaciones de sucesos', Studia Historica: Historia Moderna, 28 (2006), pp. 177-299. In Rome, Bernardino Beccari and others published avvisi on the same campaigns (Bulgarelli, Gli avvisi a stampa, nos. 242, 243, 246, 248, 250, 252-7, 261, 263, 264, 266-8, 270-4, 276, 277, 279, 280, 289-91, 293, 294). For Germany, see Roth, Die neuen Zeitungen, p. 36.

77 For the English and Italian newsletters, see Collins, Handlist of News Pamphlets, p. 45; Bulgarelli, Gli avvisi a stampa, p. 352. 
One of the most spectacular news stories in early seventeenth-century Europe was the Prince of Wales' surprise six-month visit to Madrid in 1623 in his bid to marry Philip IV's sister. That it was the scoop of the decade is shown by the fact that it inspired a superb German print of his official entry into the Spanish capital, as well as over two dozen printed newsletters in Spain, at least five in England, three in France, two each in Italy and the Netherlands, and one in Ireland. ${ }^{78}$ The anonymous contemporaneous French painting Le Colporteur shows a travelling bookseller with copies of reports in French on Prince Charles' Spanish trip tucked into his hatband.

It is perhaps not excessively surprising that events such as geographical discovery, battles, embassies, royal visits and the execution of public figures should have become international news in the course of the sixteenth century. However, the same was also true of other types of news. The severe flooding in Rome in 1530 made the news not only in Venice, but also in two Neue Zeitungenwith four known editions each — that both describe the floods in their titles as "erschröcklich" (terrifying). ${ }^{79}$ Another German newsletter on the same floods was printed at Augsburg, Munich and Strasbourg, entitled: Warhafftige anzaigung. Des grossen erschröcklichen gewessers so sich zu Rom ... begeben; and several occasionnels and canards recorded the same "terrible deluge".80 An eruption of Etna in 1536 was reported in an Italian avviso, a German Flugschrift and a Spanish relación. The earthquake that destroyed half of the city of Ferrara in 1570 is the news in various canards, in three Flugschriften, and in A coppie of the letter sent from Ferrara the xxii. of November. 1570, printed in London by Thomas Purfoot the following year. ${ }^{81}$ An Erschröckliche newe Zeytung, published in three editions in 1581, recounts the crimes committed by one Christman, who is said to have had 964 murders to his name, a sensational item that appeared in at least three canards in 1581,1582 and $1590 .{ }^{82}$ The same gory story, attributed to George Pen, was published in London in 1584 under a long title that begins: Newes out of Germanie. A most wonderfull and true discourse of a cruell murderer,

78 See Henry Ettinghausen, Prince Charles and the King of Spain's Sister-What the Papers Said (Southampton: University of Southampton, 1985). One item not mentioned there is: A Relation of the Departure of the ... Prince of Wales, from Madrid, the ninth of September ... 1623 (?London, 1623).

79 See Weller, Die ersten deutschen Zeitungen, nos. 53, 54.

80 See Seguin, L'information en France, de Louis XII à Henri II, nos. 101, 102; Seguin, L'information en France avant le périodique, nos. 123-7.

81 See Seguin, L'information en France avant le périodique, nos. 193-7; Weller, Die ersten deutschen Zeitungen, nos. 364, 365, 367; UsTC 507238.

82 See Weller, Die ersten deutschen Zeitungen, no. 543; USTC 750156, 3472, 53001. 
who had kylled in his life tyme, nine hundred, threescore and odde persons. ${ }^{83}$ The story of the conjoined twins born in the Oxfordshire village of Middleton Stoney that was told in a pamphlet printed in London in $155^{2}$ was also published in Dutch that same year in Antwerp. ${ }^{84}$

International media fame was also achieved by some monsters. The huge fish that appeared in an English newsletter in 1566 is almost certainly the same as the one described that same year in a Flugschrift printed at Augsburg. The monster engendered by witchcraft in a Spaniard near Granada, to which he gave anal birth, hit the news in a relación published in Barcelona in 1606 and in canards that came out in Rouen and then in Paris. ${ }^{85}$ And a "Horibile et maraviglioso mostro", born in Lombardy in 1578 , came to readers of the news in an illustrated Italian broadsheet, which displayed his seven heads and arms, ox's feet, and the single eye in the middle of his central head. In 1578 the same story was told in a sheet printed at Chambéry and in two German printings. And a Spanish version of the story, which set the event in the Pyrenees, was published in Madrid 76 years later, an example of the ingenious and unscrupulous recycling of old news. ${ }^{86}$

Should anyone be tempted to imagine that Renaudot's Gazette sounded the death knell for single event newsletters, it is perhaps worth recalling something that is rarely referred to: he did not just publish a weekly gazette (i.e. a digest of news items sent from various different geographical sources), but that he interspersed it, almost every week, with two other series of news pamphlets-Nouvelles ordinaires and Extraordinaires, some of the latter actually entitled Relation - that told in detail of single events, such as his account of the Catalan victory over Spain in the Battle of Montjuïc on 26 January $1641 .{ }^{87}$ Joad Raymond comments thus on the connections between what we have been referring to as newsletters and newspapers:

Though imitating Dutch models, the first newspapers emerged out of the trade in pamphlets. They were printed, published, and distributed in the same way as pamphlets, and it was not until the later seventeenth century

83 USTC 510114.

84 USTC 516524,404192 .

85 See Pierre Cordoba, 'L'Homme enceint de Grenade. Contribution à un dossier d'histoire culturelle', Mélanges de la Casa de Velázquez, 23 (1987), pp. 307-30.

86 See Folke Genert, 'Relaciones de sucesos monstruosos y las Histoires prodigieuses de Pierre de Boaistuau', in Diaz Tena, ed., Géneros editoriales y relaciones de sucesos, pp. 191-209.

87 See Relation de ce qui s'est nagveres passé en Catalogne \& ici pour les affaires de cette Principauté. 
that their ways and means of production became distinct from the pamphlet trade. ${ }^{88}$

And, just in case anyone was to suppose that modern newspapers-just because their multi-event format developed out of the seventeenth-century periodical newspaper-owe nothing to the non-periodical single event newsletters, it is worth taking note of the fact that the main news articles in this morning's paper are far more like the accounts given in single event newsletters than the little snippets of news that made up the gazettes.

88 Joad Raymond, Pamphlets and Pamphleteering in Early Modern Britain (Cambridge: Cambridge University Press, 2003), p. 101. As Thomas Schröder makes clear, the same applied in Germany, where single event newsletters "were neither thrust aside nor replaced by the newly emerging weekly press: Neue Zeitungen appeared throughout the seventeenth century”; 'Origins of the German Press', p. 130. 